\title{
Prevalence of perinatal depression among HIV-positive women: a systematic review and meta-analysis
}

\author{
Qi-Yu Zhu', De-Sheng Huang ${ }^{1,2}$, Jian-Da Lv' ${ }^{1}$ Peng Guan ${ }^{1 *}$ (iD and Xing-Hua Bai ${ }^{3}$
}

\begin{abstract}
Background: Increasing attention has been paid to differences in the prevalence of perinatal depression by HIV status, although inconsistent results have been reported. The aim of this systematic review and meta-analysis was to assess the relationship between perinatal depression and HIV infection. A comprehensive meta-analysis of comparative studies comparing the prevalence of antenatal or postnatal depression between HIV-infected women and HIV-negative controls was conducted.

Methods: Studies were identified through PubMed/Medline, Scopus, Web of Science, Cochrane Library, Embase and PsycINFO, and the reading of complementary references in August 2019. Subgroup analyses were performed for anticipated explanation of heterogeneity using methodological quality and pre-defined study characteristics, including study design, geographical location and depression screening tools for depression. The overall odds ratio $(\mathrm{OR})$ and mean prevalence of each group were calculated.

Results: Twenty-three studies (from 21 publications), thirteen regarding antenatal depression and ten regarding postnatal depression were included, comprising 3165 subjects with HIV infection and 6518 controls. The mean prevalence of antenatal depressive symptoms in thirteen included studies was 36\% (95\% Cl: 27, 45\%) in the HIVpositive group and $26 \%$ (95\% Cl: 20,32\%) in the control group. The mean prevalence of postnatal depressive symptoms in ten included studies was 21\% (95\% Cl: 14, 27\%) in the HIV-positive group and 16\% (95\% Cl: 10, 22\%) in the control group. Women living with HIV have higher odds of antenatal (OR: 1.42; 95\% Cl: 1.12, 1.80) and postnatal depressive symptoms (OR: 1.58; $95 \%$ Cl: 1.08, 2.32) compared with controls. Publication bias and moderate heterogeneity existed in the overall meta-analysis, and heterogeneity was partly explained by the subgroup analyses.
\end{abstract}

Conclusions: Women with HIV infection exhibit a significantly higher OR of antenatal and postnatal depressive symptoms compared with controls. For the health of both mother and child, clinicians should be aware of the significance of depression screening before and after delivery in this particular population and take effective measures to address depression among these women.

Keywords: HIV, Perinatal depression, Pregnant women, Meta-analysis

\footnotetext{
* Correspondence: pguan@cmu.edu.cn

'Department of Epidemiology, School of Public Health, China Medical

University, Shenyang 110122, China

Full list of author information is available at the end of the article
}

(c) The Author(s). 2019 Open Access This article is distributed under the terms of the Creative Commons Attribution 4.0 International License (http://creativecommons.org/licenses/by/4.0/), which permits unrestricted use, distribution, and reproduction in any medium, provided you give appropriate credit to the original author(s) and the source, provide a link to the Creative Commons license, and indicate if changes were made. The Creative Commons Public Domain Dedication waiver (http://creativecommons.org/publicdomain/zero/1.0/) applies to the data made available in this article, unless otherwise stated. 


\section{Background}

Human immunodeficiency virus (HIV) infection has become a major contributor to the global burden of disease, with nearly 35.3 million people infected in 2012 and sub-Saharan Africa accounting for $70.8 \%$ of the infected population [1]. Fortunately, with the introduction of antiretroviral therapy (ART), the number of AIDSrelated deaths has steadily declined, and the life expectancy of HIV-infected people has reliably increased. Now, in addition to finding treatments to prevent and cure HIV infection, attention has shifted toward improving HIV-infected people's quality of life.

Psychological health is essential to quality of life. Previous studies have shown that people living with HIV are vulnerable to mental health problems, including depression, anxiety, suicidal behaviour, and substance abuse [2]. A high prevalence of depression among HIV-infected people has been reported to result in decreased life quality, low adherence to antiretroviral medications, and increased mobility [3-5]. Moreover, a cross-sectional study concluded that among people living with HIV/AIDS, women presented more severe symptoms of depression than men [6].

It has been reported that $25.9 \%$ of women who are HIV-positive intend to have children [7], and this population might face considerable psychosocial challenges because the impact of a chronic illness could be complicated by the demands of pregnancy. A systematic review that included 22 studies conducted in Africa examined the prevalence of perinatal depression in HIV-infected women and found that the weighted mean prevalence of antenatal and postnatal depression was 23.4 and $22.5 \%$, respectively [8].

Perinatal depression, a psychiatric disorder characterized by the Diagnostic and Statistical Manual of Mental Disorders Fifth Edition (DSM-5) as a major depressive episode MDE) with peri-partum onset, i.e. symptom onset during pregnancy or in the 4 weeks following delivery, has a prevalence of 11.4 to $12.5 \%$ [9, 10]. The definition differs in research and practice, where the postpartum period has been extended to 12 months postpartum to reflect the state of the field more accurately [10]. Postnatal depression even reached a prevalence of $27.7 \%$ in one study [11]. Women with perinatal depression have increased risks of self-harm ideation, suicidal ideation, cardiovascular diseases and gestational diabetes, and depression can even induce non-adherence to ART among HIV-infected individuals [5, 12-15]. Perinatal depression usually accompanies adverse pregnancy outcomes, including premature delivery, low birth weight [16-18], and emotional, behavioural or cognitive problems in the offspring during adolescence [19]. Antenatal depression is a robust risk factor for postnatal depression, and whether the co-occurrence of this relationship with HIV infection also persists remains unknown.

Considering the adverse effects and medical demands of women with perinatal depression in the context of HIV infection, a number of studies have recently compared the prevalence of perinatal depression among HIV-infected women versus HIV-negative women and it has been found that HIV-infected women have a tendency of having perinatal depression experience [20, 21]. However, the strength of the association between HIV infection and perinatal depression remains uncertain. Antenatal and postnatal levels of depressive symptoms among HIV-infected women could afford a sound basis for the targeted treatment interventions. To the authors' knowledge, no meta-analysis has been published on this topic. To address this gap, we conducted the present meta-analysis to compare the relative risk of antenatal and postnatal depression among HIV-positive and control subjects. Subgroup analyses of study design, study quality, depression screening tool used, and geographical location were also conducted to examine anticipated heterogeneity. The present study sought to highlight the importance of accurate depression screening and prompt intervention for perinatal HIV-positive women, thereby exerting a favourable impact on the offspring.

\section{Methods}

\section{Literature search}

We used the following search strategy: (antenatal OR peripartum OR perinatal OR postnatal OR postpartum) AND (depression OR mental disorder) AND HIV. A thorough literature search was conducted through PubMed/Medline, Scopus, Web of Science, Cochrane Library, Embase and PsycINFO with the language restriction of English from inception to 3 August 2019. The search results were independently screened and extracted by two investigators (QYZ and $\mathrm{DSH}$ ), and all discrepancies were resolved by the principal investigator (PG). When data were not sufficient for metaanalysis, we tried to contact the authors through e-mail. The study was conducted in accordance with the Preferred Reporting Items for Systematic Reviews and Meta-Analyses (PRISMA) guidelines [22] (see Additional file 1).

\section{Inclusion and exclusion criteria}

Studies were eligible for inclusion if they satisfied the following criteria: 1) both an HIV-positive group and a control group were evaluated; 2) measurement tools for depression and cut-off values were reported; 3 ) antenatal depression was assessed during pregnancy, and postnatal depression was assessed no more than 1 year after delivery; 4) current rates of depression were reported or could be calculated; 5) data were provided from the earliest assessment if the study was longitudinal to preclude the influence of intervention; and 6) the study 
subjects were not recruited specifically through the mental health system to avoid the selection bias.

\section{Quality assessment}

The quality of each study was assessed according to a checklist previously used by Fisher et al. [23], which was initially developed by Mirza and Jenkins [24]. The checklist consists of nine items, including clear study aims, adequate sample size (or justification), representative sample (with justification), clear inclusion and exclusion criteria, valid and reliable measure of mental health, response rate reported and losses given, adequate description of data, appropriate statistical analysis and appropriate informed consent procedure; higher scores indicate higher quality. We defined scores of $0-3$ as low or poor quality, 4-6 as moderate quality, and 7-9 as high or good quality. Two investigators (QYZ and DSH) independently assessed article quality, and inconsistencies were resolved by the principal investigator (PG).

\section{Data analysis}

Antenatal and postnatal depression rates were metaanalysed using the fixed effects or random effects model, as appropriate. The Mentel-Haenszel method was adopted, and heterogeneity assessment was performed using $I^{2}$ statistics, with $I^{2} \geq 30 \%$ considered likely to represent moderate heterogeneity; thus, a random-effects model was used when $I^{2} \geq 30 \%$. The effect size was measured with odds ratios (ORs), and chi-square tests were used for the statistical significance test. It should be noted that these values measure significant differences in terms of the effect size. Depressive symptoms differences are measured by referring to scores on screening tools for antenatal and postnatal depressive symptoms. Mean prevalence was calculated with a random model based on the number of participants in each study, and $95 \%$ confidence intervals (95\% CIs) were also calculated. Publication bias was assessed with visual inspection of the funnel plots. The above-mentioned statistical analyses were performed using the software Review Manager, Version 5.3 (RevMan 5.3), and Stata, Version 13.0.

\section{Sensitivity analysis}

Considering that our meta-analysis consisted of different study types, perinatal depression was defined by various screening tools, and the studies were conducted in different geographic regions, the following subgroup analyses were also assessed the robustness of the results: methodological quality, study design, study quality, depression screening tool used, and geographical location.

\section{Results}

Characteristics of included studies

A total of 1098 articles were found using the search strategy, and 603 publications remained after duplicates were removed. After reviewing in depth of these publications and obtaining necessary data by contacting the authors, 26 studies (24 articles) met the inclusion criteria. Due to the overlap of the study populations, only 23 studies (21 articles) were finally included in the metaanalysis [20, 21, 25-43]; thirteen studies reported antenatal depression, and ten studies reported postnatal depression (Fig. 1). One article that focused on antenatal depression defined people with unknown serostatus of HIV as controls [33] and the other studies defined HIVnegative people as controls. In total, 1520 subjects with HIV infection and 4383 controls were included in the meta-analysis of antenatal depression, and 1645 subjects living with HIV infection and 2135 controls were included in the meta-analysis of postnatal depression.

Table 1 shows the characteristics of the included studies [20, 21, 25-43]. Of the 23 studies included in our metaanalysis, eleven used the Edinburgh Postnatal Depression Scale (EPDS) for depression screening; the Center for Epidemiologic Studies Depression Scale (CES-D) was adopted by six studies; the Self-Reporting Questionnaire (SRQ) was applied in three studies; one study measured depression by the diagnostic Structured Clinical Interview for DSM-IV Axis I Disorders (SCID); one study used the Shona Symptom Questionnaire (SSQ); and the remaining study used the International Classification of Diseases 10th Revision (ICD-10) depression inventory (Major Depression Inventory). While the EPDS and SRQ are used with different cut-off values, the most frequently used cutoff for the EPDS was 13, used by nine studies, and the remaining two studies used cut-off values of 11 and 12 . The analysis was first carried out without restriction of the original EPDS cut-off values, and then we also calculated the effect size when excluding the studies that adopted EPDS cut-off values below 13. For the three studies that used the SRQ, two defined 7 as the cut-off value, and the remaining one used a cut-off value of 8 . Table 2 shows the methodological quality of the included studies.

\section{Meta-analysis of antenatal depression}

The mean prevalence of antenatal depressive symptoms in thirteen included studies was 36\% (95\% CI: 27, 45\%) in the HIV-positive group and $26 \%$ (95\% CI: $20,32 \%$ ) in the control group. The meta-analysis showed a significantly increased odds ratio (OR) of antenatal depressive symptoms in the HIV infection group compared with controls (OR: 1.42; 95\% CI: 1.12, 1.80), with moderate heterogeneity $I^{2}=55 \%, P=0.004$ (Fig. 2). The fixedeffects model showed a pooled OR of 1.32 (95\% CI: 1.15, 1.52). When we excluded the study that used individuals 


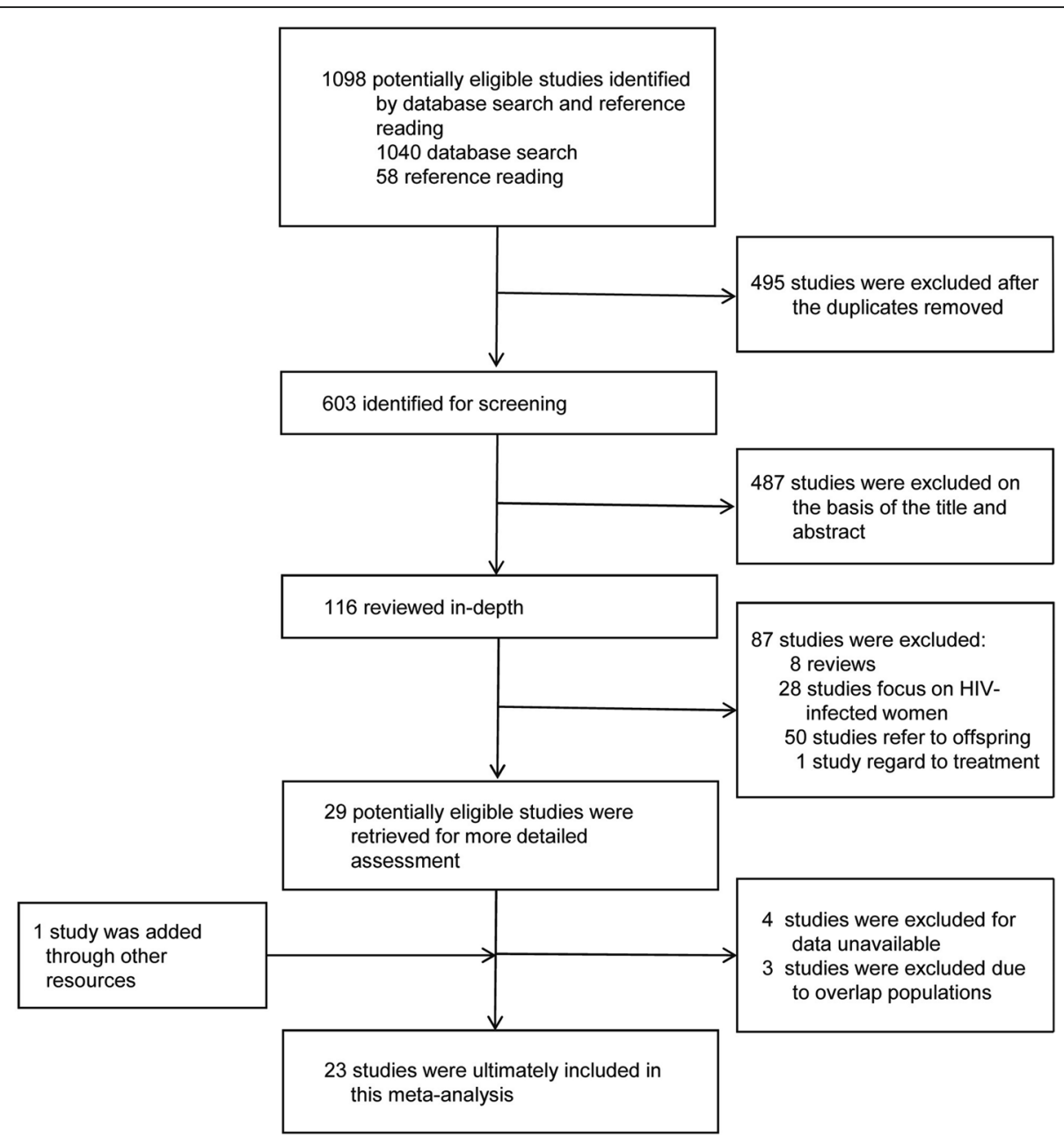

Fig. 1 PRISMA flow diagram of study selection process of antenatal and postnatal depression in women with HIV infection compared with controls

with unknown HIV serostatus as controls, the result did not change significantly (OR: $1.44 ; 95 \%$ CI: $1.12,1.86$, random-effects model).

Our pre-specified sensitivity analyses are reported in Table 3. There were no differences among the subgroups when stratified by any methodological characteristics except the geographical location where the study was conducted; the studies that were conducted in Africa showed a higher OR than studies conducted in North America $(P=0.03)$. A funnel plot indicated the existence of publication bias, as a few included studies had a small sample size and reported negative findings (Fig. 3).

\section{Meta-analysis of postnatal depression}

The mean prevalence of postnatal depressive symptoms in ten included studies was $21 \%$ (95\% CI: 14, 27\%) in the HIV-positive group and $16 \%$ (95\% CI: 10, 22\%) in the control group. The meta-analysis showed a significantly increased odds ratio of postnatal depressive symptoms in the HIV-infected group compared with the controls (OR: 1.58; 95\% CI: 1.08, 2.32), with moderate heterogeneity $I^{2}=65 \%, P=0.002$ (Fig. 4). The fixed-effects model showed a pooled OR of 1.39 (95\% CI: 1.13, 1.71). However, when we excluded studies that used the EPDS with a cut-off value below the recommended 13, the odds ratio changed to 1.56 (95\% CI: 0.98, 2.47).

The pre-specified sensitivity analyses are reported in Table 3 and Additional file 2: Figures S5-S8. Differences were found among subgroups based on methodological quality, depression screening tool, and geographical locations. The high-quality studies showed a higher OR than the medium-quality studies $(P<0.01)$, and statistically significant differences were found among the studies with different study designs, including cross-sectional, case-control and longitudinal study $(P<0.01)$. The studies that were conducted in Africa showed a higher OR than those conducted in North America $(P=0.01)$. A funnel plot showed the existence of publication bias as a 
Table 1 Characteristics of included studies of antenatal depression and postnatal depression in HIV-infected women compared with controls

\begin{tabular}{|c|c|c|c|c|c|c|c|c|c|}
\hline $\begin{array}{l}\text { Study } \\
\text { (Author, year } \\
\text { of publication) }\end{array}$ & $\begin{array}{l}\text { Country } \\
\text { and location }\end{array}$ & $\mathrm{N}$ & Type of study & Time of assessment & $\begin{array}{l}\text { Instrument and } \\
\text { cutoff value }\end{array}$ & $\mathrm{HIV+}$ & Controls & $\begin{array}{l}\text { Number } \\
\text { with } \\
\text { depression in } \\
\text { HIV+ group }\end{array}$ & $\begin{array}{l}\text { Number } \\
\text { with } \\
\text { depression } \\
\text { in control } \\
\text { group }\end{array}$ \\
\hline \multicolumn{10}{|l|}{ Antenatal } \\
\hline $\begin{array}{l}\text { Bonacquisti et al., } \\
2014 \text { [25] }\end{array}$ & $\begin{array}{l}\text { America, Urban, } \\
1 \text { obstetrics/ } \\
\text { gynecology clinic }\end{array}$ & 163 & $\begin{array}{l}\text { Case-control } \\
\text { study }\end{array}$ & 24 weeks & CES-D $\geq 16$ & 50 & 113 & 18 & 41 \\
\hline $\begin{array}{l}\text { Collin et al., } \\
2006[26]\end{array}$ & $\begin{array}{l}\text { Zambia, Urban, } \\
1 \text { antenatal clinic }\end{array}$ & 181 & $\begin{array}{l}\text { Cross- } \\
\text { sectional }\end{array}$ & 33 weeks & SRQ-20 $\geq 7$ & 89 & 92 & 20 & 20 \\
\hline $\begin{array}{l}\text { Malqvist et al., } \\
2016 \text { [27] }\end{array}$ & $\begin{array}{l}\text { Swaziland, } \\
\text { Peri-urban }\end{array}$ & 973 & Cross-sectional & $\begin{array}{l}\text { 3rd trimester } \\
\text { of pregnancy }\end{array}$ & $E P D S \geq 13$ & 412 & 561 & 105 & 117 \\
\hline $\begin{array}{l}\text { Manikkam and } \\
\text { Burns, } \\
2012 \text { [28] }\end{array}$ & $\begin{array}{l}\text { South Africa, } \\
\text { Urban, Antenatal } \\
\text { clinic at } \\
\text { tertiary hospital }\end{array}$ & 378 & Cross-sectional & 28.6 weeks mean & $E P D S \geq 13$ & 104 & 201 & 44 & 66 \\
\hline $\begin{array}{l}\text { Manongi et al., } \\
2017 \text { [29] }\end{array}$ & $\begin{array}{l}\text { Tanzania, } \\
\text { Semi-urban, Antenatal } \\
\text { care clinic }\end{array}$ & 1116 & Cross-sectional & 24 weeks & $E P D S \geq 13$ & 38 & 1078 & 11 & 117 \\
\hline $\begin{array}{l}\text { Natamba et al., } \\
2014 \text { [30] }\end{array}$ & $\begin{array}{l}\text { Uganda, Urban, } \\
1 \text { antenatal } \\
\text { care clinic } \\
\text { other public } \\
\text { medical facilities }\end{array}$ & 123 & $\begin{array}{l}\text { Case-control } \\
\text { study }\end{array}$ & 18 weeks & CES-D $\geq 16$ & 36 & 87 & 19 & 25 \\
\hline $\begin{array}{l}\text { Nydoo et al., } \\
2017 \text { [20] }\end{array}$ & $\begin{array}{l}\text { South Africa, } \\
\text { Urban, } 2 \\
\text { antenatal clinics }\end{array}$ & 102 & Cross-sectional & $\begin{array}{l}\text { 1st trimester } \\
\text { of pregnancy }\end{array}$ & $E P D S \geq 13$ & 40 & 62 & 2 & 8 \\
\hline $\begin{array}{l}\text { Osok et al., } \\
2018 \text { [21] }\end{array}$ & $\begin{array}{l}\text { Kenyan, Rural, } \\
\text { Maternal child } \\
\text { health clinic }\end{array}$ & 176 & Cross-sectional & Not provided & $E P D S \geq 13$ & 14 & 162 & 13 & 45 \\
\hline $\begin{array}{l}\text { Rochat et al., } \\
2011 \text { [31] }\end{array}$ & $\begin{array}{l}\text { South Africa, Rural, } \\
1 \text { primary health } \\
\text { care clinic }\end{array}$ & 109 & Cross-sectional & $\begin{array}{l}\text { second half } \\
\text { of pregnancy }\end{array}$ & SCID & 49 & 60 & 27 & 24 \\
\hline $\begin{array}{l}\text { Rubin et al., } \\
2011 \text { [32] }\end{array}$ & $\begin{array}{l}\text { America, Urban, } \\
6 \text { clinic sites }\end{array}$ & 244 & Longitudinal & $\begin{array}{l}\leq 10 \text { months } \\
\text { before delivery }\end{array}$ & CES-D $\geq 16$ & 139 & 105 & 47 & 40 \\
\hline $\begin{array}{l}\text { Stranix-Chibanda } \\
\text { et al., } 2005 \text { [33] }\end{array}$ & $\begin{array}{l}\text { Zimbabwe, Peri-urban, } \\
3 \text { antenatal clinics }\end{array}$ & 437 & Cross-sectional & $\begin{array}{l}\text { 3rd trimester } \\
\text { of pregnancy }\end{array}$ & $S S Q \geq 8$ & 62 & 212 & 12 & 35 \\
\hline $\begin{array}{l}\text { Thomas et al., } \\
2017 \text { [34] }\end{array}$ & $\begin{array}{l}\text { South Africa, Rural, } 2 \\
\text { primary health } \\
\text { care clinics }\end{array}$ & 899 & Cohort study & 28-32 weeks & EPDS $\geq 13$ & 192 & 707 & 51 & 174 \\
\hline $\begin{array}{l}\text { Tomlinson et al., } \\
2018 \text { [35] }\end{array}$ & $\begin{array}{l}\text { South Africa, Urban, } \\
\text { Community sample }\end{array}$ & 1241 & $\begin{array}{l}\text { randomised } \\
\text { controlled trial }\end{array}$ & 26 weeks & EPDS $>13$ & 295 & 943 & 113 & 320 \\
\hline \multicolumn{10}{|l|}{ Postnatal } \\
\hline $\begin{array}{l}\text { Aaron et al., } \\
2015 \text { [36] }\end{array}$ & $\begin{array}{l}\text { America, Urban, } 1 \\
\text { obstetrics/ } \\
\text { gynecology clinic }\end{array}$ & 162 & $\begin{array}{l}\text { Case-control } \\
\text { study }\end{array}$ & 6 months & CES-D > 16 & 49 & 113 & 15 & 25 \\
\hline $\begin{array}{l}\text { Chersich et al., } \\
2008 \text { [37] }\end{array}$ & $\begin{array}{l}\text { Kenya, Urban, a } \\
\text { pediatric clinic in } \\
\text { provincial hospital }\end{array}$ & 500 & Cross-sectional & 1 year & ICD-10 & 54 & 446 & 2 & 6 \\
\hline $\begin{array}{l}\text { Chibanda et al., } \\
2014 \text { [38] }\end{array}$ & $\begin{array}{l}\text { Zimbabwe, Peri-urban, } \\
2 \text { postnatal clinics }\end{array}$ & 210 & Cross-sectional & $6-8$ weeks & $E P D S \geq 11$ & 31 & 148 & 14 & 35 \\
\hline $\begin{array}{l}\text { Collin et al., } \\
2006 \text { [26] }\end{array}$ & $\begin{array}{l}\text { Zambia, Urban, } \\
1 \text { antenatal clinic }\end{array}$ & 181 & Cross-sectional & 7 days & $S R Q-20 \geq 7$ & 89 & 92 & 4 & 6 \\
\hline $\begin{array}{l}\text { Cyimana et al., } \\
2010 \text { [39] }\end{array}$ & $\begin{array}{l}\text { Zambia, Urban, } \\
\text { University teaching } \\
\text { tertiary hospital }\end{array}$ & 229 & Cross-sectional & 2-6 weeks & $E P D S \geq 13$ & 46 & 183 & 17 & 47 \\
\hline
\end{tabular}


Table 1 Characteristics of included studies of antenatal depression and postnatal depression in HIV-infected women compared with controls (Continued)

\begin{tabular}{|c|c|c|c|c|c|c|c|c|c|}
\hline $\begin{array}{l}\text { Study } \\
\text { (Author, year } \\
\text { of publication) }\end{array}$ & $\begin{array}{l}\text { Country } \\
\text { and location }\end{array}$ & $\mathrm{N}$ & Type of study & Time of assessment & $\begin{array}{l}\text { Instrument and } \\
\text { cutoff value }\end{array}$ & $\mathrm{HIV+}$ & Controls & $\begin{array}{l}\text { Number } \\
\text { with } \\
\text { depression in } \\
\text { HIV+ group }\end{array}$ & $\begin{array}{l}\text { Number } \\
\text { with } \\
\text { depression } \\
\text { in control } \\
\text { group }\end{array}$ \\
\hline $\begin{array}{l}\text { Dow et al., } \\
2014 \text { [40] }\end{array}$ & $\begin{array}{l}\text { Malawi, Urban } \\
\text { primary clinic and } \\
\text { peri-urban clinic }\end{array}$ & 492 & Longitudinal & 10-14 weeks & $E P D S \geq 12$ & 338 & 154 & 39 & 15 \\
\hline $\begin{array}{l}\text { Mokhele et al., } \\
2019 \text { [41] }\end{array}$ & $\begin{array}{l}\text { South Africa, N/A, } \\
\text { Midwife } \\
\text { Obstetric Units }\end{array}$ & 1151 & Cross-sectional & 1 month & CES-D $10 \geq 10$ & 690 & 461 & 70 & 50 \\
\hline $\begin{array}{l}\text { Okronipa et al., } \\
2012 \text { [42] }\end{array}$ & $\begin{array}{l}\text { Ghana, Rural, } 3 \\
\text { prenatal clinics }\end{array}$ & 328 & Cross-sectional & 6 months & $E P D S \geq 13$ & 152 & 176 & 26 & 5 \\
\hline $\begin{array}{l}\text { Rubin et al., } \\
2011 \text { [32] }\end{array}$ & $\begin{array}{l}\text { America, Urban, } \\
6 \text { clinic sites }\end{array}$ & 244 & Longitudinal & $\begin{array}{l}\leq 12 \text { months } \\
\text { after delivery }\end{array}$ & CES-D $\geq 16$ & 139 & 105 & 43 & 37 \\
\hline $\begin{array}{l}\text { Stewart et al., } \\
2008 \text { [43] }\end{array}$ & $\begin{array}{l}\text { Malawi, Rural, Child } \\
\text { health clinic at } \\
\text { government hospital }\end{array}$ & 501 & Cross-sectional & 9.9 month mean & $S R Q-20 \geq 8$ & 57 & 257 & 25 & 67 \\
\hline
\end{tabular}

Abbreviations: CES-D Centre for Epidemiologic Surveys for Depression, EPDS Edinburgh Postnatal Depression Scale, HIV+ HIV positive, ICD-10 International Classification of Diseases-10 depression inventory (Major Depression Inventory), SCID Structured Clinical Interview for DSM-IV Axis I Disorders, SRQ-20 SelfReporting Questionnaire, SSQ Shona Symptom Questionnaire

few included studies had a small sample size and reported negative findings (Fig. 5).

\section{Discussion}

While several reviews have discussed the relationship between HIV infection and depression [44-46] and two reviews focused on the perinatal mental health of women with HIV infection $[8,47]$, more specific aspects made the present systematic review more unique. The disease burden of antenatal and postnatal depression among HIV-infected women could provide reference to develop appropriate screening programs and targeted interventions to reduce the negative health outcomes for the mothers and their babies. To our knowledge, this is the first meta-analysis to compare the prevalence of antenatal and postnatal depressive symptoms among HIVinfected women and controls. Our meta-analysis, which consisted of 23 studies, suggested that women living with HIV had a higher odds ratio of antenatal and postnatal depression compared with controls. This result is in accordance with several previous studies that suggested a high prevalence of antenatal and postnatal depression among HIV-infected women [48, 49].

For perinatal depression, depressive symptoms were measured with different screening tools. The most commonly used measurement tool was the EPDS; eleven of the 23 included studies used it in our meta-analysis. The present meta-analysis included studies with different measurement tools for perinatal depressive symptoms, even the same measurement tool with different cut-off values. As we shown in our results, when we excluded the studies of which screening tool EPDS cut-off values were below 13, the odds ratio varied from 1.58 (95\% CI: $1.08,2.32)$ to 1.56 (95\% CI: $0.98,2.47)$. Thus, it was indicated that the adoption of screening tools for depressive symptoms and the choice of cut-off value should be considered in the meta-analysis that including studies with different screening tools.

While the prevalence of antenatal and postnatal depression in HIV-infected women was modestly higher than that in controls, significant clinical effects may be associated with this difference. Several studies have focused on the complexity of the causal pathways between HIV infection and depression, and extensive evidence has been found that the persistent existence of the virus in the central nervous system could result in neurobiological changes that might cause depression in HIVinfected individuals [50-55]. Del Guerra et al. conducted a review to examine the key role of neuroendocrine, immunoinflammatory, and monoaminergic mechanisms in the development of depression among HIV-infected patients [50]. Few studies have focused on the mechanisms of depression in pregnant women with HIV, and it is of great significance to study the effects of HIV infection on pregnant women and their offspring. The mean prevalence of antenatal depression in HIV-positive and controls was 36 and $26 \%$, respectively, which was relatively high. This could be partly explained by the fact that the depressive symptoms were measured based on various screening tools, and this also drew the attention to the depression during antenatal care. A systematic review by Sowa et al. has reported a prevalence of $43.5 \%$ of susceptible antenatal depression among HIV-positive women, which is similar to ours [8]. 
Table 2 Quality evaluation of studies included in the meta-analysis

\begin{tabular}{|c|c|c|c|c|c|c|c|c|c|c|}
\hline $\begin{array}{l}\text { Study (first } \\
\text { author, } \\
\text { publication year) }\end{array}$ & $\begin{array}{l}\text { Clear } \\
\text { study } \\
\text { aims }\end{array}$ & $\begin{array}{l}\text { Adequate sample } \\
\text { size (or justification) }\end{array}$ & $\begin{array}{l}\text { Representative } \\
\text { sample (with } \\
\text { justification) }\end{array}$ & $\begin{array}{l}\text { Clear } \\
\text { inclusion } \\
\text { and } \\
\text { exclusion } \\
\text { criteria }\end{array}$ & $\begin{array}{l}\text { Measure } \\
\text { of mental } \\
\text { health } \\
\text { valid and } \\
\text { reliable }\end{array}$ & $\begin{array}{l}\text { Response } \\
\text { rate } \\
\text { reported } \\
\text { and losses } \\
\text { reported }\end{array}$ & $\begin{array}{l}\text { Adequate } \\
\text { description } \\
\text { of data }\end{array}$ & $\begin{array}{l}\text { Appropriate } \\
\text { statistical } \\
\text { analysis }\end{array}$ & $\begin{array}{l}\text { Appropriate } \\
\text { informed } \\
\text { consent } \\
\text { procedure }\end{array}$ & $\begin{array}{l}\text { Total } \\
\text { score }\end{array}$ \\
\hline $\begin{array}{l}\text { Aaron et al. } \\
2015 \text { [36] }\end{array}$ & 1 & 1 & 0 & 1 & 1 & 0 & 1 & 1 & 1 & 7 \\
\hline $\begin{array}{l}\text { Bonacquisti et al. } \\
2014 \text { [25] }\end{array}$ & 1 & 1 & 0 & 1 & 1 & 0 & 1 & 1 & 0 & 6 \\
\hline $\begin{array}{l}\text { Chersich et al. } \\
2008 \text { [37] }\end{array}$ & 1 & 1 & 0 & 1 & 1 & 1 & 1 & 1 & 0 & 7 \\
\hline $\begin{array}{l}\text { Chibanda et al. } \\
2014 \text { [38] }\end{array}$ & 1 & 0 & 1 & 1 & 1 & 0 & 1 & 1 & 1 & 7 \\
\hline $\begin{array}{l}\text { Collin et al. } \\
2006 \text { [26] }\end{array}$ & 1 & 0 & 0 & 1 & 1 & 1 & 1 & 1 & 1 & 7 \\
\hline $\begin{array}{l}\text { Cyimana et al. } \\
2010 \text { [39] }\end{array}$ & 1 & 1 & 1 & 0 & 1 & 0 & 1 & 1 & 1 & 7 \\
\hline $\begin{array}{l}\text { Dow et al. } \\
2014 \text { [40] }\end{array}$ & 1 & 0 & 0 & 0 & 1 & 1 & 1 & 1 & 1 & 6 \\
\hline $\begin{array}{l}\text { Malqvist et al. } \\
2016 \text { [27] }\end{array}$ & 1 & 1 & 0 & 1 & 1 & 1 & 1 & 1 & 1 & 8 \\
\hline $\begin{array}{l}\text { Manikkam } \\
\text { and Burns } \\
2012[28]\end{array}$ & 1 & 1 & 0 & 1 & 1 & 1 & 1 & 1 & 1 & 8 \\
\hline $\begin{array}{l}\text { Manongi et al. } \\
2017 \text { [29] }\end{array}$ & 1 & 1 & 0 & 1 & 1 & 0 & 1 & 1 & 0 & 6 \\
\hline $\begin{array}{l}\text { Mokhele et al. } \\
2019 \text { [41] }\end{array}$ & 1 & 1 & 0 & 1 & 1 & 1 & 1 & 1 & 1 & 8 \\
\hline $\begin{array}{l}\text { Natamba et al. } \\
2014 \text { [30] }\end{array}$ & 1 & 0 & 0 & 1 & 1 & 1 & 1 & 1 & 1 & 7 \\
\hline $\begin{array}{l}\text { Nydoo et al. } \\
2017 \text { [20] }\end{array}$ & 1 & 0 & 0 & 1 & 1 & 0 & 1 & 1 & 1 & 6 \\
\hline $\begin{array}{l}\text { Okronipa et al. } \\
2012 \text { [42] }\end{array}$ & 1 & 1 & 0 & 1 & 1 & 1 & 1 & 1 & 1 & 8 \\
\hline $\begin{array}{l}\text { Osok et al. } \\
2018 \text { [21] }\end{array}$ & 1 & 1 & 0 & 0 & 1 & 0 & 1 & 1 & 1 & 6 \\
\hline $\begin{array}{l}\text { Rochat et al. } \\
2011 \text { [31] }\end{array}$ & 1 & 0 & 0 & 1 & 1 & 1 & 1 & 1 & 1 & 7 \\
\hline $\begin{array}{l}\text { Rubin et al. } \\
2011 \text { [32] }\end{array}$ & 1 & 0 & 0 & 1 & 1 & 0 & 1 & 1 & 1 & 6 \\
\hline $\begin{array}{l}\text { Stewart et al. } \\
2008 \text { [43] }\end{array}$ & 1 & 1 & 0 & 1 & 1 & 1 & 1 & 1 & 0 & 7 \\
\hline $\begin{array}{l}\text { Stranix-Chibanda } \\
\text { et al. } \\
2005 \text { [33] }\end{array}$ & 1 & 0 & 0 & 1 & 1 & 1 & 1 & 1 & 0 & 6 \\
\hline $\begin{array}{l}\text { Thomas et al. } \\
2017 \text { [34] }\end{array}$ & 1 & 1 & 0 & 1 & 1 & 0 & 1 & 1 & 1 & 7 \\
\hline $\begin{array}{l}\text { Tomlinson et al. } \\
2018 \text { [35] }\end{array}$ & 1 & 1 & 1 & 1 & 1 & 1 & 1 & 1 & 1 & 9 \\
\hline
\end{tabular}

Furthermore, antenatal depression might be a risk factor for postnatal depression [56]. Verreault et al. found that among women with postnatal depression, most have experienced depression during pregnancy, and only $6.6 \%$ were new cases [57]. While adverse foetal and maternal outcomes and non-adherence to ART and prenatal care are associated with untreated perinatal depression [5, 12-19], some studies proved that both maternal and foetal physical health and psychosocial outcomes can be improved with proper intervention [58]. Therefore, it is imperative to improve prenatal care and ART adherence among HIV-infected women. A meta-analysis revealed that ART 


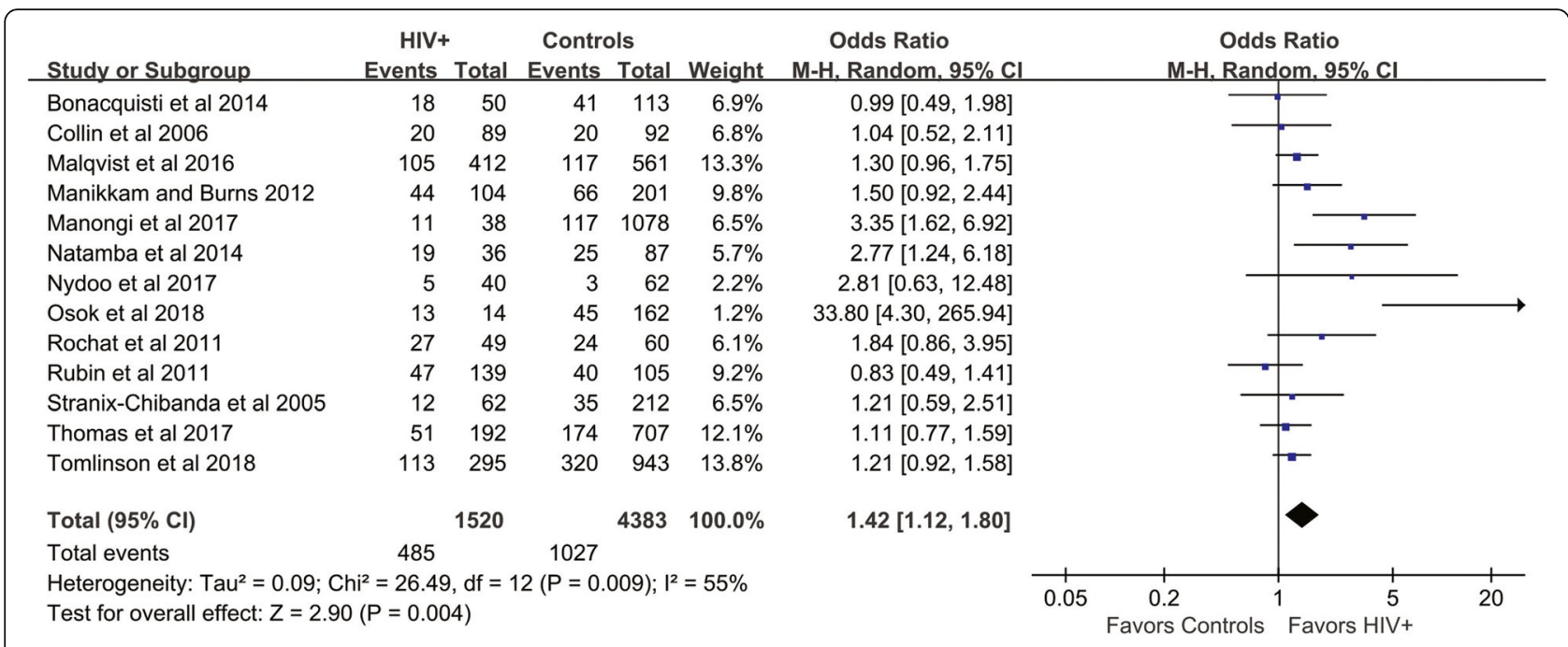

Fig. 2 Forest plot of all included studies of antenatal depression in HIV-infected women compare with controls

adherence was improved with the application of treatments for depression and psychological distress [59]. According to our results that in the HIV-positive group the prevalence of antenatal and postnatal depressive symptoms was 36 and $21 \%$, respectively, which was relatively high, thus it is imperative to take action in this particular population.

Gestation is associated with diverse physiological changes and can be regarded as the most effective period for depression screening and treatment. Given the large

Table 3 Sensitivity analyses of methodological characteristics

\begin{tabular}{|c|c|c|c|c|c|c|c|c|c|c|}
\hline \multicolumn{6}{|l|}{ Antenatal depression } & \multicolumn{5}{|c|}{ Postnatal depression } \\
\hline & $\begin{array}{l}\text { Number } \\
\text { of studies }\end{array}$ & $\begin{array}{l}\text { Total number } \\
\text { of subjects } \\
\text { (HIV+/controls) }\end{array}$ & OR $(95 \% \mathrm{Cl})$ & $P^{2}(\%)$ & $P$ & $\begin{array}{l}\text { Number } \\
\text { of studies }\end{array}$ & $\begin{array}{l}\text { Total number } \\
\text { of subjects } \\
\text { (HIV+/controls) }\end{array}$ & OR $(95 \% \mathrm{Cl})$ & $P^{2}(\%)$ & $P$ \\
\hline \multicolumn{11}{|l|}{ Meta-analysis } \\
\hline Random-effects model & 13 & $1520 / 4383$ & $1.42(1.12,1.80)$ & 55 & & 10 & $1645 / 2135$ & $1.58(1.08,2.32)$ & 65 & \\
\hline Fixed-effects model & 13 & $1520 / 4383$ & $1.32(1.15,1.52)$ & 55 & & 10 & $1645 / 2135$ & $1.39(1.13,1.71)$ & 65 & \\
\hline \multicolumn{11}{|l|}{ Sub group analysis } \\
\hline Methodological quality & & & & & 0.31 & & & & & 0.04 \\
\hline Low & 0 & & & & & 0 & & & & \\
\hline Medium & 6 & $343 / 1732$ & $1.88(0.93,3.79)$ & 76 & & 2 & $477 / 259$ & $0.97(0.64,1.46)$ & 0 & \\
\hline High & 7 & $1177 / 2651$ & $1.29(1.11,1.51)$ & 0 & & 8 & $1168 / 1876$ & $1.86(1.16,2.98)$ & 67 & \\
\hline Study design & & & & & 0.11 & & & & & 0.13 \\
\hline Cross-sectional & 8 & $808 / 2428$ & $1.74(1.19,2.54)$ & 58 & & 7 & $1119 / 1763$ & $1.92(1.11,3.34)$ & 72 & \\
\hline Case-control & 2 & $86 / 200$ & $1.62(0.59,4.45)$ & 73 & & 1 & $49 / 113$ & $1.55(0.73,3.30)$ & & \\
\hline Other & 3 & $626 / 1755$ & $1.11(0.91,1.36)$ & 0 & & 2 & $477 / 259$ & $0.97(0.64,1.46)$ & 0 & \\
\hline Depression screening tool & & & & & 0.71 & & & & & 0.04 \\
\hline EPDS & 7 & $1095 / 3714$ & $1.58(1.13,2.21)$ & 67 & & 4 & $567 / 661$ & $2.31(1.17,4.56)$ & 69 & \\
\hline CES-D & 3 & $225 / 305$ & $1.25(0.63,2.47)$ & 68 & & 3 & $878 / 679$ & $0.97(0.72,1.29)$ & 0 & \\
\hline Other & 3 & $200 / 364$ & $1.30(0.86,1.99)$ & 0 & & 3 & 200/795 & $1.73(0.82,3.65)$ & 32 & \\
\hline Geographical locations & & & & & 0.03 & & & & & 0.19 \\
\hline Africa & 11 & $1331 / 4165$ & $1.55(1.20,2.01)$ & 56 & & 8 & 1457/1917 & $1.78(1.12,2.84)$ & 68 & \\
\hline North America & 2 & $189 / 218$ & $0.88(0.58,1.35)$ & 0 & & 2 & $188 / 218$ & $1.07(0.58,1.97)$ & & \\
\hline
\end{tabular}




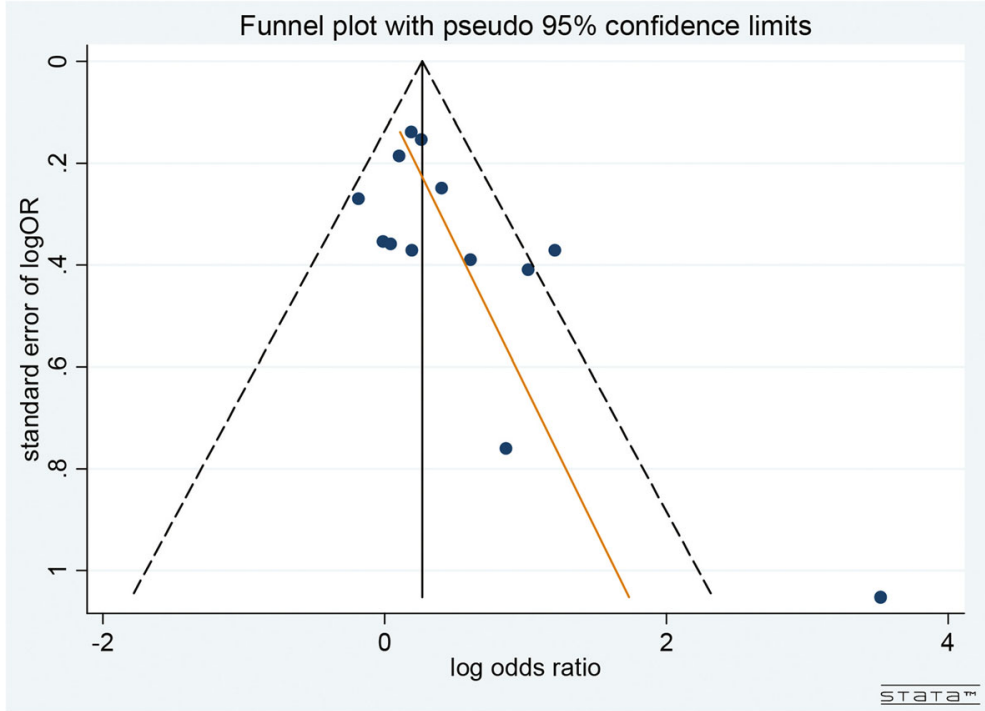

Fig. 3 Funnel plot to assess for publication bias in antenatal studies

number of HIV-infected women, it is a major challenge for local medical systems to meet their prenatal health needs by offering both medical and psychological interventions. Regular prenatal care not only protects women's physical and psychological health in the postpartum but also decreases the mothers' risk to have low birth weight, preterm, and small for gestational age babies [60]. The depression rate is also significantly decreased among HIV-infected individuals who receive social support [61]. Some studies have confirmed that adherence to ART decreased during the postpartum period when antenatal depression persisted after delivery [62-64]. In addition, improved prenatal psychological health may contribute to postpartum emotional adjustment, thus helping to establish a good maternal-child bond, enhancing the mother's social skills and expanding her social support network in a virtuous circle. For perinatal depression, available interventions found to be efficacious generally consist of cognitive-behavioural and interpersonal therapy approaches [65, 66]; and among them, for example, the Mothers and Babies course is a cognitive-behavioural intervention that has shown promise as an intervention for low-income women at risk for postnatal mood issues [67]. The intervention during the antenatal and postnatal period need to be further explored and assessed, the optimal management of comorbid HIV and depression should also be further investigated.

There are some strengths in this study. First, it is the first meta-analysis to compare the prevalence of perinatal

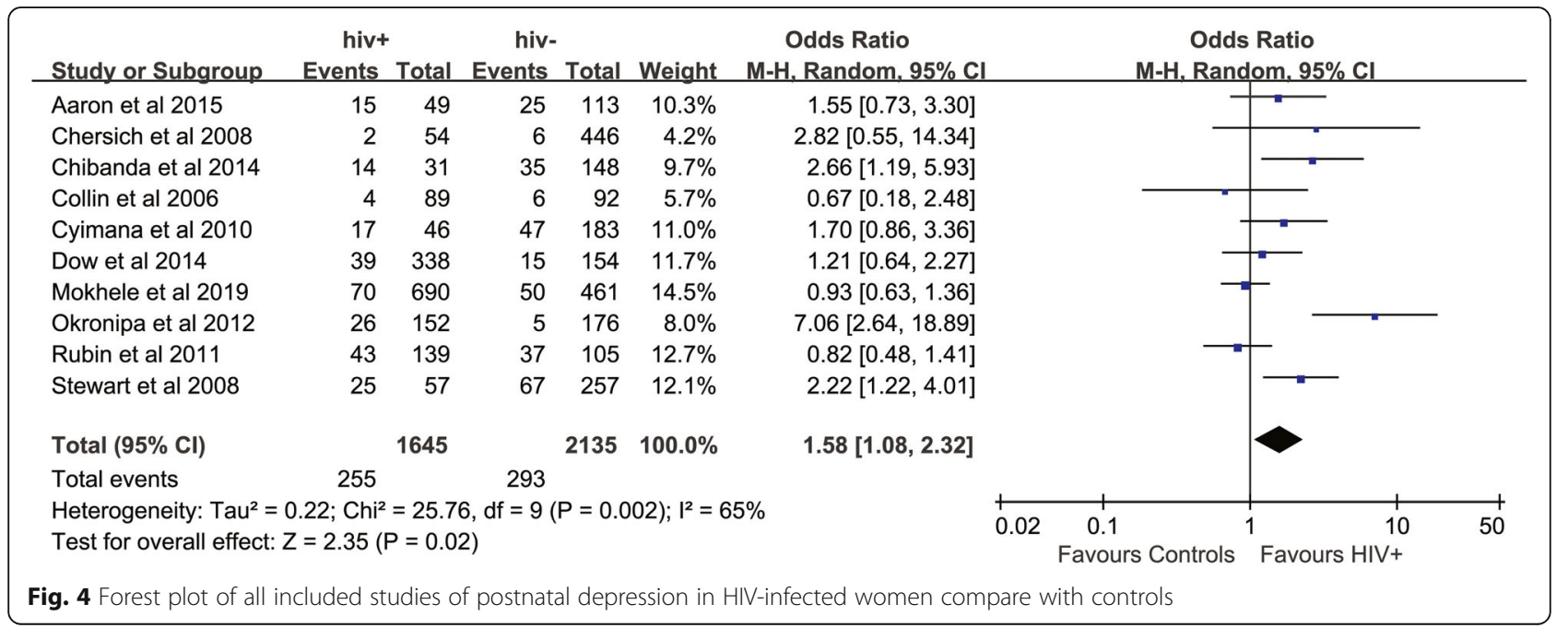




\section{Funnel plot with pseudo 95\% confidence limits}

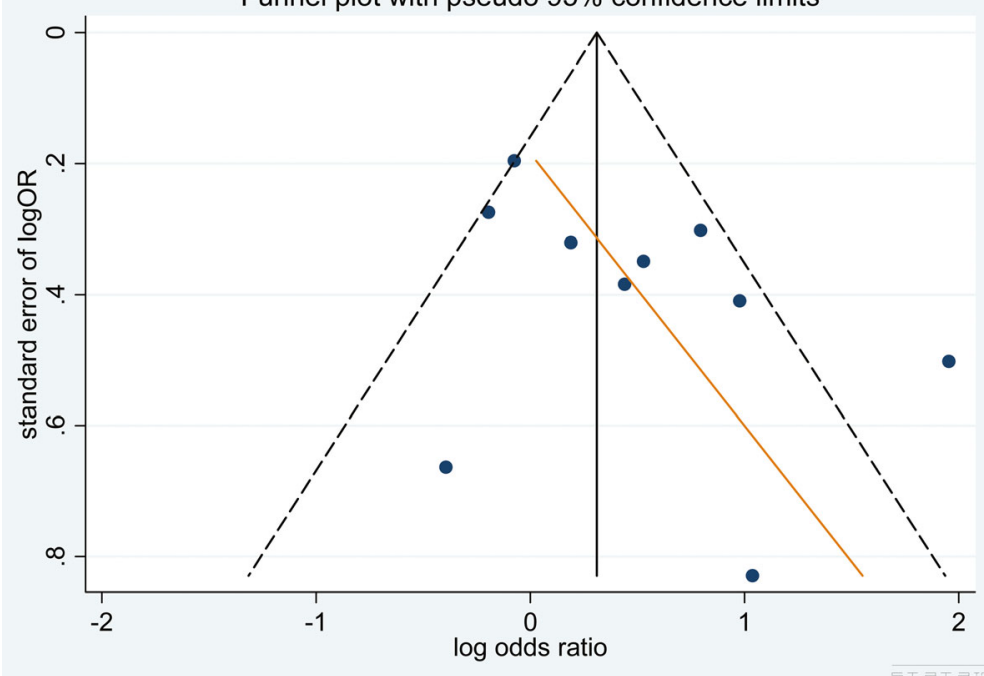

Fig. 5 Funnel plot to assess for publication bias in postnatal studies

depression symptoms between HIV-infected women and controls, which could add to guidelines for the treatment of this population. Second, the synthesis and analysis of a large number of studies from countries in Africa with a high HIV prevalence suggests a higher risk of both antenatal and postnatal depression among women living with HIV infection, adding evidence to previous articles that focused on the high prevalence of depression among HIV-positive women $[8,46]$. Because the prevalence of antenatal and postnatal depression rather than mean scores could be obtained from the included studies, mean prevalence of antenatal and postnatal depressive symptoms could be calculated, and thus we found that prevalence of antenatal depressive symptoms was much higher than that of postnatal depressive symptoms. This might be partly explained that the characteristics of the populations in the two different sets of publications were different. And this also implies that there may be a biological relationship between HIV and depression that is seen in the biological environment of pregnancy but not postpartum, which merits further attention and investigation.

Nevertheless, several limitations exist in this study. First, screening tools were used to measure depressive symptoms rather than depression, and the same cut-off values of each screening tool were not used in all studies, so we should cautiously apply the results to the population. Second, because the baseline of each study was not exactly the same and individual information was not available, and the heterogeneity cannot be fully explained by subgroup analysis. Third, six types of screening tools were used to detect perinatal depression. While the EPDS was designed specifically for pregnant women, the application of other tools might not be suitable and might have contributed to the heterogeneity. Fourth, the studies that we included had a variety of study designs, which might be another contributor to the heterogeneity.

\section{Conclusions}

Our meta-analysis demonstrates a significantly increased risk of antenatal and postnatal depressive symptoms in women with HIV infection, and the findings emphasize the need for the optimal management of comorbid HIV and depression. Future studies should focus on the longitudinal follow-up of women with HIV infection, the causal pathways between HIV and perinatal depression and the long-term impact of HIV-related treatments on antenatal and postnatal depression in this high-risk population.

\section{Supplementary information}

Supplementary information accompanies this paper at https://doi.org/10 1186/s12888-019-2321-2.

Additional file 1. PRISMA checklist

Additional file 2. Supplemental Figures for subgroup analyses

\section{Abbreviations \\ ART: Antiretroviral therapy; CES-D: Centre for Epidemiologic Surveys for Depression; Cl: Confidence interval; DSM-5: The Diagnostic and Statistical Manual of Mental Disorders Fifth Edition; EPDS: Edinburgh Postnatal Depression Scale; HIV: Human immunodeficiency virus; ICD-10: International Classification of Diseases 10th Revision; MDE: Major depressive episode; OR: Odds ratio; RevMan: Review Manager; SCID: Diagnostic Structured Clinical Interview for DSM-IV Axis I Disorders; SRQ: Self-Reporting Questionnaire}

\section{Acknowledgements}

The authors would like to acknowledge the work of the research teams whose publications were included in this meta-analysis. 


\section{Authors' contributions}

All authors contributed to the design of the study. QYZ, DSH, JDL, and XHB collected the data. QYZ, DSH and PG conducted the quality evaluation of the included studies and QYZ, DSH and XHB performed the data analysis. QYZ and PG wrote the initial draft of the paper. All authors read and approved the final manuscript.

\section{Funding}

This work is partly supported by the Science Foundation of Liaoning Provincial Department of Education (Grant No. LK201659). The funding source had no role in the study design, data collection, analysis and interpretation, or in the writing of this manuscript.

\section{Availability of data and materials}

All data generated or analyzed during this study are included in this published article.

\section{Ethics approval and consent to participate}

Not applicable.

\section{Consent for publication}

Not applicable.

\section{Competing interests}

The authors declare that they have no competing interests.

\section{Author details}

'Department of Epidemiology, School of Public Health, China Medical University, Shenyang 110122, China. ${ }^{2}$ Department of Mathematics, School of Fundamental Sciences, China Medical University, Shenyang, China. ${ }^{3}$ Department of Radiation Oncology, The First Affiliated Hospital of China Medical University, Shenyang, China.

Received: 26 February 2019 Accepted: 14 October 2019

Published online: 30 October 2019

\section{References}

1. Maartens G, Celum C, Lewin SR. HIV infection: epidemiology, pathogenesis, treatment, and prevention. Lancet. 2014;384(9939):258-71.

2. Niu L, Luo D, Liu Y, Silenzio VM, Xiao S. The mental health of people living with HIV in China, 1998-2014: a systematic review. PLoS One. 2016;11(4): e0153489.

3. Ciesla JA, Roberts JE. Meta-analysis of the relationship between HIV infection and risk for depressive disorders. Am J Psychiatry. 2001; 158(5): $725-30$.

4. Ickovics JR, Hamburger ME, Vlahov D, Schoenbaum EE, Schuman P, Boland RJ, et al. HIV epidemiology research study group. Mortality, CD4 cell count decline, and depressive symptoms among HIV-seropositive women: longitudinal analysis from the HIV epidemiology research study. JAMA. 2001;285(11):1466-74.

5. Uthman OA, Magidson JF, Safren SA, Nachega JB. Depression and adherence to antiretroviral therapy in low-, middle- and high-income countries: a systematic review and meta-analysis. Curr HIV/AIDS Rep. 2014; 11(3):291-307.

6. Reis RK, Haas VJ, Santos CB, Teles SA, Galvao MT, Gir E. Symptoms of depression and quality of life of people living with HIV/AIDS. Rev Lat Am Enfermagem. 2011;19(4):874-81.

7. Ramos de Souza M, do Amaral WN, Alves Guimarães R, Rezza G, Brunini SM. Reproductive desire among women living with HIV/AIDS in Central Brazil: Prevalence and associated factors. PLoS One. 2017;12(10):e0186267.

8. Sowa NA, Cholera R, Pence BW, Gaynes BN. Perinatal depression in HIVinfected African women: a systematic review. J Clin Psychiatry. 2015; 76(10):1385-96.

9. American Psychiatric Association. Diagnostic and statistical manual of mental disorders, 5 ed. American Psychiatric Publishing, Arlington, 2013.

10. Woody CA, Ferrari AJ, Siskind DJ, Whiteford HA, Harris MG. A systematic review and meta-regression of the prevalence and incidence of perinatal depression. J Affect Disord. 2017:219:86-92.

11. Chang HP, Chen JY, Huang YH, Tyan JY, Yeh CJ, Su PH, et al. Prevalence and factors associated with depressive symptoms in mothers with infants or toddlers. Pediatr Neonatol. 2014;55(6):470-9.
12. Wisner KL, Sit DK, McShea MC, Rizzo DM, Zoretich RA, Hughes CL, et al. Onset timing, thoughts of self-harm, and diagnoses in postpartum women with screen-positive depression findings. JAMA Psychiatry. 2013;70(5):490-8.

13. Rochat TJ, Bland RM, Tomlinson M, Stein A. Suicide ideation, depression and HIV among pregnant women in rural South Africa. Health. 2013; 5(3A):650-61.

14. Vaccarino V, Johnson BD, Sheps DS, Reis SE, Kelsey SF, Bittner V, et al. National Heart, Lung, and Blood Institute. Depression, inflammation, and incident cardiovascular disease in women with suspected coronary ischemia: the National Heart, Lung, and Blood Institute-sponsored WISE study. J Am Coll Cardiol. 2007;50(21):2044-50

15. Varela P, Spyropoulou AC, Kalogerakis Z, Vousoura E, Moraitou M, Zervas IM. Association between gestational diabetes and perinatal depressive symptoms: evidence from a Greek cohort study. Prim Health Care Res Dev. 2017;18(5):441-7.

16. Grigoriadis $\mathrm{S}$, VonderPorten $\mathrm{EH}$, Mamisashvili L, Tomlinson $\mathrm{G}$, Dennis $\mathrm{CL}$, Koren $\mathrm{G}$, et al. The impact of maternal depression during pregnancy on perinatal outcomes: a systematic review and meta-analysis. J Clin Psychiatry. 2013;74(4):e321-41.

17. Jarde A, Morais M, Kingston D, Giallo R, MacQueen GM, Giglia L, et al. Neonatal outcomes in women with untreated antenatal depression compared with women without depression: a systematic review and metaanalysis. JAMA Psychiatry. 2016;73(8):826-37.

18. Wisner KL, Sit DK, Hanusa BH, Moses-Kolko EL, Bogen DL, Hunker DF, et al. Major depression and antidepressant treatment: impact on pregnancy and neonatal outcomes. Am J Psychiatry. 2009;166(5):557-66.

19. Bauer A, Pawlby S, Plant DT, King D, Pariante CM, Knapp M. Perinatal depression and child development: exploring the economic consequences from a South London cohort. Psychol Med. 2015;45(1):51-61.

20. Nydoo P, Naicker T, Moodley J. Depressive scores in newly diagnosed HIV-infected and HIV-uninfected pregnant women. S Afr J Psychiatry. 2017;23:1085.

21. Osok J, Kigamwa P, Stoep AV, Huang KY, Kumar M. Depression and its psychosocial risk factors in pregnant Kenyan adolescents: a crosssectional study in a community health Centre of Nairobi. BMC Psychiatry. 2018;18(1):136.

22. Moher D, Liberati A, Tetzlaff J, Altman DG, PRISMA Group. Preferred reporting items for systematic reviews and meta-analyses: the PRISMA statement. PLoS Med. 2009;6(7):e1000097.

23. Fisher J, Cabral de Mello M, Patel V, Rahman A, Tran T, et al. Prevalence and determinants of common perinatal mental disorders in women in low- and lower-middle-income countries: a systematic review. Bull World Health Organ. 2012;90(2):139G-49G

24. Mirza I, Jenkins R. Risk factors, prevalence, and treatment of anxiety and depressive disorders in Pakistan: systematic review. BMJ. 2004:328(7443):794.

25. Bonacquisti A, Geller PA, Aaron E. Rates and predictors of prenatal depression in women living with and without HIV. AIDS Care. 2014; 26(1):100-6.

26. Collin SM, Chisenga MM, Kasonka L, Haworth A, Young C, Filteau S, et al. Factors associated with postpartum physical and mental morbidity among women with known HIV status in Lusaka, Zambia. AIDS Care. 2006; 18(7):812-20

27. Malqvist M, Clarke K, Matsebula T, Bergman M, Tomlinson M. Screening for antepartum depression through community health outreach in Swaziland. J Community Health. 2016:41(5):946-52.

28. Manikkam L, Burns JK. Antenatal depression and its risk factors: an urban prevalence study in KwaZulu-Natal. S Afr Med J. 2012;102(12):940-4.

29. Manongi R, Rogathi J, Sigalla G, Mushi D, Rasch V, Gammeltoft T, et al. The Association Between Intimate Partner Violence and Signs of Depression During Pregnancy in Kilimanjaro Region, Northern Tanzania. J Interpers Violence. 2017. https://doi.org/10.1177/0886260517724256.

30. Natamba BK, Achan J, Arbach A, Oyok TO, Ghosh S, Mehta S, et al. Reliability and validity of the center for epidemiologic studies-depression scale in screening for depression among HIV-infected and -uninfected pregnant women attending antenatal services in northern Uganda: a cross-sectional study. BMC Psychiatry. 2014;14:303.

31. Rochat TJ, Tomlinson M, Barnighausen T, Newell ML, Stein A. The prevalence and clinical presentation of antenatal depression in rural South Africa. J Affect Disord. 2011;135(1-3):362-73.

32. Rubin LH, Cook JA, Grey DD, Weber K, Wells C, Golub ET, et al. Perinatal depressive symptoms in HIV-infected versus HIV-uninfected women: a 
prospective study from preconception to postpartum. J Women's Health (Larchmt). 2011;20(9):1287-95.

33. Stranix-Chibanda L, Chibanda D, Chingono A, Montgomery E, Wells J, Maldonado Y, et al. Screening for psychological morbidity in HIV-infected and HIV-uninfected pregnant women using community counselors in Zimbabwe. J Int Assoc Physicians AIDS Care (Chic). 2005:4(4):83-8.

34. Thomas E, Kuo C, Cohen S, Hoare J, Koen N, Barnett W, et al. Mental health predictors of breastfeeding initiation and continuation among HIV infected and uninfected women in a south African birth cohort study. Prev Med. 2017;102:100-11.

35. Tomlinson M, Rotheram-Borus MJ, Scheffler A, le Roux I. Antenatal depressed mood and child cognitive and physical growth at 18-months in South Africa: a cluster randomised controlled trial of home visiting by community health workers. Epidemiol Psychiatr Sci. 2018;27(6):601-10.

36. Aaron E, Bonacquisti A, Geller PA, Polansky M. Perinatal depression and anxiety in women with and without human immunodeficiency virus infection. Womens Health Issues. 2015;25(5):579-85.

37. Chersich MF, Luchters SM, Yard E, Othigo JM, Kley N, Temmerman M. Morbidity in the first year postpartum among HIV-infected women in Kenya. Int J Gynaecol Obstet. 2008;100(1):45-51.

38. Chibanda D, Shetty AK, Tshimanga M, Woelk G, Stranix-Chibanda L, Rusakaniko S. Group problem-solving therapy for postnatal depression among HIV-positive and HIV-negative mothers in Zimbabwe. J Int Assoc Provid AIDS Care. 2014;13(4):335-41.

39. Cyimana A, Andrews B, Ahmed Y, Vwalika B. HIV/AIDS and postnatal depression at the university teaching hospital, Lusaka, Zambia. Med J Zambia. 2010;37(2):78-83.

40. Dow A, Dube Q, Pence BW, Van Rie A. Postpartum depression and HIV infection among women in Malawi. J Acquir Immune Defic Syndr. 2014; 65(3):359-65.

41. Mokhele I, Nattey C, Jinga N, Mongwenyana C, Fox MP, Onoya D. Prevalence and predictors of postpartum depression by HIV status and timing of HIV diagnosis in Gauteng, South Africa. PLoS One. 2019;14(4): e0214849.

42. Okronipa HE, Marquis GS, Lartey A, Brakohiapa L, Perez-Escamilla R, Mazur RE. Postnatal depression symptoms are associated with increased diarrhea among infants of HIV-positive Ghanaian mothers. AIDS Behav. 2012;16(8): 2216-25.

43. Stewart RC, Umar E, Kauye F, Bunn J, Vokhiwa M, Fitzgerald M, et al. Maternal common mental disorder and infant growth--a cross-sectional study from Malawi. Matern Child Nutr. 2008;4(3):209-19.

44. Arseniou S, Arvaniti A, Samakouri M. HIV infection and depression. Psychiatry Clin Neurosci. 2014;68(2):96-109.

45. Benton TD. Depression and HIV/AIDS. Curr Psychiatry Rep. 2008;10(3):280-5.

46. Bernard C, Dabis F, de Rekeneire N. Prevalence and factors associated with depression in people living with HIV in sub-Saharan Africa: a systematic review and meta-analysis. PLoS One. 2017;12(8):e0181960.

47. Kapetanovic S, Dass-Brailsford P, Nora D, Talisman N. Mental health of HIVseropositive women during pregnancy and postpartum period: a comprehensive literature review. AIDS Behav. 2014;18(6):1152-73.

48. Ramirez-Avila L, Regan S, Giddy J, Chetty S, Ross D, Katz JN, et al. Depressive symptoms and their impact on health-seeking behaviors in newlydiagnosed HIV-infected patients in Durban, South Africa. AIDS Behav. 2012; 16(8):2226-35.

49. Rochat TJ, Richter LM, Doll HA, Buthelezi NP, Tomkins A, Stein A. Depression among pregnant rural south African women undergoing HIV testing. JAMA. 2006;295(12):1376-8.

50. Del Guerra FB, Fonseca JLI, Figueiredo VM, Ziff EB, Konkiewitz EC. Human immunodeficiency virus-associated depression: contributions of immunoinflammatory, monoaminergic, neurodegenerative, and neurotrophic pathways. J Neuro-Oncol. 2013;19(4):314-27.

51. Barreto ICG, Viegas P, Ziff EB, Konkiewitz EC. Animal models for depression associated with HIV-1 infection. J Neurolmmune Pharmacol. 2014;9(2):195-208.

52. Benatti C, Blom JM, Rigillo G, Alboni S, Zizzi F, Torta R, et al. Disease-induced Neuroinflammation and depression. CNS Neurol Disord Drug Targets. 2016; 15(4):414-33.

53. Ferrell D, Giunta B. The impact of HIV-1 on neurogenesis: implications for HAND. Cell Mol Life Sci. 2014;71(22):4387-92.

54. Mcarthur JC, Brew BJ, Avi NJLN. Neurological complications of HIV infection. Lancet Neurol. 2005;4(9):543-55.
55. del Palacio M, Alvarez S, Muñoz-Fernández MÁ. HIV-1 infection and neurocognitive impairment in the current era. Rev Med Virol. 2012;22(1):33-45.

56. Underwood L, Waldie K, D'Souza S, Peterson ER, Morton S. A review of longitudinal studies on antenatal and postnatal depression. Arch Womens Ment Health. 2016;19(5):711-20.

57. Verreault N, Da Costa D, Marchand A, Ireland K, Dritsa M, Khalifé S. Rates and risk factors associated with depressive symptoms during pregnancy and with postpartum onset. J Psychosom Obstet Gynaecol. 2014;35(3):84-91.

58. National Collaborating Centre for Mental Health (UK). Antenatal and Postnatal Mental Health: Clinical Management and Service Guidance: Updated edition. Leicester: British Psychological Society; 2014. (NICE Clinical Guidelines, No. 192.) Available from: https://www.ncbi.nlm.nih.gov/books/ NBK305023/

59. Sin NL, Dimatteo MR. Depression treatment enhances adherence to antiretroviral therapy: a meta-analysis. Ann Behav Med. 2014;47(3):259-69.

60. Chen $\mathrm{CH}$, Lin HC. Prenatal care and adverse pregnancy outcomes among women with depression: a nationwide population-based study. Can J Psychiatr. 2011:56(5):273-80.

61. Matsumoto S, Yamaoka K, Takahashi K, Tanuma J, Mizushima D, Do CD, et al. Social support as a key protective factor against depression in HIVinfected patients: report from large HIV clinics in Hanoi, Vietnam. Sci Rep. 2017:7(1):15489.

62. Robertson E, Grace S, Wallington T, Stewart DE. Antenatal risk factors for postpartum depression: a synthesis of recent literature. Gen Hosp Psychiatry. 2004;26(4):289-95.

63. Mellins CA, Chu C, Malee K, Allison S, Smith R, Harris L, et al. Adherence to antiretroviral treatment among pregnant and postpartum HIV-infected women. AIDS Care. 2008;20(8):958-68.

64. Cohn SE, Umbleja T, Mrus J, Bardeguez AD, Andersen JW, Chesney MA. Prior illicit drug use and missed prenatal vitamins predict nonadherence to antiretroviral therapy in pregnancy: adherence analysis A5084. AIDS Patient Care STDs. 2008;22(1):29-40.

65. Sockol LE, Epperson CN, Barber JP. Preventing postpartum depression: a meta-analytic review. Clin Psychol Rev. 2013;33(8):1205-17.

66. Dennis CL. Psychosocial interventions for the treatment of perinatal depression. Best Pract Res Clin Obstet Gynaecol. 2014;28(1):97-111.

67. Le HN, Perry DF, Mendelson T, Tandon SD, Muñoz RF. Preventing perinatal depression in high risk women: moving the mothers and babies course from clinical trials to community implementation. Matern Child Health J. 2015;19:2102-10.

\section{Publisher's Note}

Springer Nature remains neutral with regard to jurisdictional claims in published maps and institutional affiliations.

\section{Ready to submit your research? Choose BMC and benefit from:}

- fast, convenient online submission

- thorough peer review by experienced researchers in your field

- rapid publication on acceptance

- support for research data, including large and complex data types

- gold Open Access which fosters wider collaboration and increased citations

- maximum visibility for your research: over $100 \mathrm{M}$ website views per year

At BMC, research is always in progress.

Learn more biomedcentral.com/submissions 